\title{
Energy Audit Report On a Technical Institute
}

\author{
${ }^{1}$ Dr.K.Umesha, M.E, Phd, ${ }^{2}$ Miste.Mieee (Madras Section) \\ Jawaharlal College of Engineering and Technology, Lakkidi, Palakkad district, Kerala, India, Vice Principal \\ and $\mathrm{HOD} / \mathrm{ECE}$,
}

\begin{abstract}
Energy auditing has been conducted to the Jawaharlal College of Engineering \& Technology to estimate the Energy consumed in a day, week and monthly. The Energy Auditing for a day is the index of the consumption which normalizes the situation of Energy crisis by providing the conservation schemes. Any organization so called bulk consumer of electrical energy propose to adopt suitable technology or scheme of energy conservation to minimize. The unwanted power shutdown either incidentally or by load shedding.

Energy auditing has been a part and parcel of every consumer of any form of which energy is exhaustible and inexhaustible in nature. In olden days their practice used to exploitation of energy only when it is available for example during crops harvesting wind blow in one direction was very essential for that they used wait overnight whenever wind blows little heavily harvesting process used to be done.aslo they used select the season for harvesting exclusively for this purpose because ample labours were also available there will not rain and sufficient sun is available people will not be having any work in the field. That is how energy by nature was used by formers. Now we are being literate energy being used without bothering its existence further. Energy auditing is one tool through which balancing of demand and supply is determined and the positive mismatch cannot be compensated either by organic way or it might be difficult task.
\end{abstract}

Keywords: conservation, feasibility, recommendations, payback period.

\section{Introduction}

Energy auditing in a integral part of energy conservation and energy management is also part and parallel of conservation. Damage and supply gap is large energy to lead to similar natural defects. Energy disaster such as Tsunami and earth quake. The next generation generating yet to come will be completely light blind. It is because power never be available after this disaster and not ever rehabilitate the reconstruction of buildings. To avoid the energy calamity proposed auditing report use the innovative energy utilization schemes through which the ferocious of situation might blindness can be eradicated.

\section{A. Energy Audit Types and Methodology}

\section{Energy Audit Options at a Glance \& Recommendations}

The "Energy Audit" is the key to a systematic approach for decision-making in the area of energy management. It attempts to balance the total energy inputs with their use, and serves to identify all the energy streams in a facility. It quantifies energy usage according to its discrete functions. Energy audit is an effective tool in defining and pursuing a comprehensive energy management program within a business. As per the Energy Conservation Act, 2001, passed by the government of India, energy audit is defined as "the verification, monitoring and analysis of use of energy including submission of technical reports containing recommendations for improving energy efficiency with cost benefit analysis and an action plan to reduce energy consumption."

\section{B. Need for Energy Audit}

In an organization like Engineering College, the top operating expense is often found to be electrical energy. In most assessments of the manageability of the cost or potential cost savings in the above component, would invariably emerge as a top priority, and thus energy Audit.

Energy constitutes a strategic area for cost reduction. A well done energy audit will always help owners to understand more about the ways energy is used in their organizations, and help to identify areas where waste can occur and where scope for improvement exists.

The energy audit would give a positive orientation to the energy cost reduction, preventive maintenance, and quality control programs which are vital for production and utility activities. Such an audit program will help to keep focus on variations that occur in the energy costs, availability, and reliability of supply of energy, help decide on the appropriate energy mix, identify energy conservation technologies, retrofit for energy conservation equipment, etc.In general, the energy audit is the translation of conservation ideas and hopes into reality, by lending technically feasible solutions with economic and other organizational considerations within a specified time frame. 
The primary objective of the energy audit is to determine ways to reduce energy consumption per unit of product output or to lower operating costs. The energy audit provides a benchmark, or reference point, for managing and assessing energy use across the organization and provides the basis for ensuring more effective use of energy.

\section{C.Types of Energy Audits}

The type of energy audit to be performed depends on:

- Function and type of organization

- Depth to which a final audit is needed, and

- Potential and magnitude of cost reduction desired

Thus energy audits can be classified into the following two types:

- Preliminary audit

- Detailed audit

\section{D.Preliminary Energy Audit Methodology}

The preliminary energy audit uses existing or easily obtained data. It is a relatively quick exercise to:

- Determine energy consumption in the organization

- Estimate the scope for saving

- Identify the most likely (and easiest areas) for attention

- Identify immediate (especially no-cost/low-cost) improvements/savings

- Set a reference point

- Identify areas for more detailed study/measurement

\section{E.Detailed Energy Audit Methodology}

A detailed energy audit provides a comprehensive energy project implementation plan for a facility, since it evaluates all major energy-using systems.

This type of audit offers the most accurate estimate of energy savings and cost. It considers the interactive effects of all projects, accounts for the energy use of all major equipment, and includes detailed energy cost saving calculations and project cost.

In a detailed audit, one of the key elements is the energy balance. This is based on an inventory of energy-using systems, assumptions of current operating conditions, and calculations of energy use. This estimated use is then compared to utility bill charges.

\section{F.Detailed Energy Auditing Is Carried Out In Three Phases:}

Phase I - Pre-Audit

Phase II - Audit

Phase III - Post-Audit

G.The Information To Be Collected During The Detailed Audit Includes:

1. Energy consumption by type of energy, by department, by major equipment.

2. Energy cost and tariff data

3. Sources of energy supply (e.g., electricity off the grid or self-generation)

4. Energy Management procedures and energy awareness training programs within the establishment

\section{H. Process Flow Diagram To Identify Energy Wastage}

\section{Investment}

Equipment cost

Cost of Civil works

Cost of Instrumentation

Cost of Auxiliaries

\section{Annual operating cost}

Cost of capital

Maintenance cost

Manpower

Energy cost

Depreciation cost 


\section{Annual Savings}

Electrical energy

Net Savings $/$ Year $=($ Annual savings- Annual operating costs $)$

Payback period in months $=($ Investment/net savings/year $) / 12$

\section{Classification Of Energy Conservation Measures}

Based on the Energy Audit and analysis of the organization, a number of energy saving schemes may be identified. These may be classified into three categories:

1. Low cost - high return

2. Medium cost - medium return

3. High cost - high return

\section{Priority Economic Feasibility}

Priority of energy audit reveals that the replacement of LCD desktop computers little economically not feasible if the issue is taken as short term but as long term goal it is recommended.

Similarly the immediate replacement of conventionally controlled fans with remote controlled fans is also economically not feasible only it is the recommendation for the use in newly constructed buildings.

\section{Technical Feasibility}

All issues taken for energy saving are considered as technically feasible in all the cases there is a technical importance to promote the energy conservation measures in all levels of infrastructure development and modernization of existing system in the coming years.

\section{Risk Feasibility}

Risk factors of any change or alteration or modification of the existing system are the prime factors of implementation careful planning and execution as per set plan with minimum depreciation and maintenance cost may reduce the invest burden reasonably. Corrective and preventive measures always indicate the progressive economic stability for the organization which reduces the risk factor mean time technology change will act as beneficial fact for further implementation.

\section{A. Energy Audit Instruments}

\section{Instruments Used In The Energy Audit}

The requirement for an energy audit such as identification and quantification of energy necessitates various measurements; these measurements require the use of instruments. These instruments must be portable, durable, easy to operate and relatively inexpensive. The parameters generally monitored during the energy audit may include the following:

Basic Electrical Parameters in AC \& DC systems - Voltage (V), Current (I), Power factor, Active power $(\mathrm{kW})$, Energy consumption $(\mathrm{kWh})$, Harmonics, etc.

Parameters of importance other than electrical such as temperature, radiation

\section{B.Electrical Measuring Instruments}

These are instruments for measuring major electrical parameters such as, kW, PF, Hertz, amps and volts. in addition some of these instruments also measure harmonics. These instruments are applied on-line, i.e., on running motors without stopping the motor. Instantaneous measurements can be taken with hand-held meters,

C.Lux Meter

Illumination levels are measured with a lux meter.

\section{Table 1: Type And Priority Of Energy-Saving Measures Annual Electrical Energy}

\section{Savings Priority}

\section{A: No Investment (Immediate \\ Operational improvement \\ Housekeeping}

\section{B: Low Investment Short to medium term)}

Controls Equipment modification

Process change 


\section{C: High Investment (Long term)}

Energyefficientdevices

Product modification Technology Change

\section{Sample Reporting Format For Energy Conservation Recommendations}

\section{A. Recommendations}

1) Pump the cooled water to cold storage plant during night to thermally insulated tank. Advice people not to use cold water till 12 noon of the day. Only they have to use the cold water plant between 12 noon to-10 PM for 10 hours.

2) Workers/Employees are advised to use only cotton clothes. White or relatively white cloth during summer. Therefore they can avoid too much sweating with that the effect of dehydration can be minimized and the water consumption can be minimized through which cold water storage burden will reduce at least by 10 $20 \%$ of total consumption.

3) They can use cotton mini size umbrella it is not for rain protection it is exclusively to protect for direct attack of solar radiations, when they walk outside during afternoon. So that soon after reaching home fan use can be minimized and it is healthy after going home immediate use of AC or FAN should be avoided as biologically certain harmonically imbalance takes place .gradual body cooling is better.

4) Use focused light for reading place or table lamp. Sometime recommended to avoid full room lighting it leads to wastage of illumination and disturbance of sleep to housemates which disturb their work efficiency at working place. Man-hour efficiency reduction is the national waste.aslo insufficient sleeps leads to health problems.

5) All Interior walls should be painted using Enameled paint which would reflect light

6) All Air conditional rooms should be Air light and doors should be Hydraulic closing system. Outside air entry in to the air conditioned room is not hygienic.

7) One special provision can be made for cooled water storage facility wherever possible attached AC room, so that multipurpose utilization of AC to cool the water will reduce the power consumption by $30 \%$.

8) Good light ventilation and Air ventilation to classrooms may solve the problem of Energy Consumption.

9) Replacement of CRT monitor by LCD monitor not only gives the cost benefit interns of energy saving but also play a significant role of radiations due high potential .when CRT is used high voltage level handling by CRT at HT electrodes may emit harmful radiations beyond the screen which affect the vision .human being get in touch for trouble shooting may receive great risk of deadly shock if they touch the charged body which is normally charged up to 10000 volts(approximately) In LCD monitor all such problems can be minimized.

10) Energy saving by replacing LCD desktop with LAPTOP illustrate the benefits in terms of portability, space saving, maintenance cost of desktop computers and additional cost of peripherals. Also cost of damage and other electrical problems. Critical space management and cost involved can be removed. Wiring for LAN and labour cost can also be prevented.

11) Unnecessary power consumption by negligence of user and system administrator for not switching off while leaving the office will have more vulnerability for damage due to short circuit and heavy voltage due to lightning .

12) It is recommended to replace fluorescent lamps by CFL which are handy by construction and possibility of breakage is less. Installation is easy and the labour charge required for replacement of burnt tubes and defected choke lamps is a costly affair. Disposal of burnt tubes will disturb the habitat place of both human being and animals. The release of krypton and argon gases is more dangerous, it may lead to ecological imbalance if it in mass destruction.

13) Switch off the photocopier machine at the main outlet itself when not in use or in other words machine should not be kept in stand by and sleep mode which consumes power.

14) Avoiding individual mobile phone facility at the working place during working hours is better; as they use charging facility which consume power and substandard battery chargers draws more current leads to more power consumption. There is also possibility66 of electrical short circuit. Common communication facility may lead to harmony among employs due to uniform facility it keeps the working atmosphere very clean and calm in addition to the cost benefit.

15) Use good lighting system will reduce the power burden as a whole.

16) Energy recycling, when Equipment is operating or motor is running is the research area where young generations have to address.

17) Fans running without capacitor or under rated capacitor will draw more current therefore use of correct rated capacitor will reduce the power consumption. 
18) All major equipments should run with good power factor and the integration of Instrument to read the P. F online should be made mandatory. Therefore immediate care can be taken to improve the power factor.

19) Recommended to use Online harmonics measurement system to monitor the harmonics higher level harmonics lead generate heat in the equipment may lead to greater power loss .Harmonics suppression equipment is necessary.

20) Recommended to use solar water cooler in place of conventional one

\section{B.List of Utilities}

Fluorescent \& CFL lamps

Regulator Controlled ceiling and wall mounted Fans

Modem Power pack

Desktop Computer with LCD Monitor

Laser Printer

Laptop Computer

Mobile Phone Charger

Photocopier

Telephone Power pack

Water cooler

Air conditioning

\section{Description Of Existing System And Its Operation:}

Location selected: Administrative Block. Jawaharlal College of Engineering \& Technology, Jawaharlal, Jawahar Gardens, Lakkidi, Palakkad (District).

\section{Existing system consists of the following}

I. Low level space: total built area

Physics lab measuring

$=417.28 \mathrm{sqm}$

Store measuring

$=12.19 \times 16.53 \mathrm{sqm}$

$=12.19 \times 9.14 \mathrm{sqm}$

II.Ground Floor: Total built up area $=1433.36$ sqm

Office1 measuring

Office-2 measuring

CAD lab measuring

$=12.10 \times 16.38 \mathrm{sqm}$

$=12.19 \times 9.14 \mathrm{sqm}$

Computer lab: measuring

$=12.19 \times 9.14 \mathrm{Sqm}$

Principal measuring

$=12.19 \times 21.49 \mathrm{Sqm}$

Staff room-1measuring

$=29.6 \times 16$ feet

Ladies rest room measuring

$=12.19 \times 8.13 \mathrm{Sqm}$

$=12.108 .23 \mathrm{Sqm}$

Administrative office: Total area=1433.36sqmor 15423sqft

Establishment / account sector-OFFICE-1

Office-2: measuring

$$
=12.19 \times 16.38 \mathrm{sqm}
$$

Principal Room - 1: Total area $=10$ sqm 290x160sqft

Office- 2 consists of the following

Management and Director Room

Chairman rooms

Managing Trustee room

Secretary room

Academic director room

Personal assistant open space

Cabin - 1

Cabin -2

Public utility area

Internet Lab $\quad=40 X 108 \mathrm{sqft}$ or $12.19 \mathrm{X} 21.48 \mathrm{sqm}$

Faculty room.

Ladies rest room:

Examination Section

Staircase - $1 \& 2$

CAD LAB 
III. First floor-total built-up area=1898.23sqmtr

Library measuring

$=12.19 \times 38.10 \mathrm{sqm}$.

Ups room

$=4.58 \times 4.38 \mathrm{sqm}$

$\mathrm{CR}-1$ to4 measuring

$=12.19 \times 9.14 \mathrm{sqm}$

Toilet $-1 \& 2$ measuring

$=4.48 \times 7.06 \mathrm{sqm}$

Chemistry Lab -1 measuring $\quad=12.19 \times 16.38 \mathrm{sqm}$

Electronics Lab $1 \& 2$ measuring $\quad=12.19 \times 16.38 \mathrm{sqm}$

Board room measuring

$=9 \mathrm{x} 4.56 \mathrm{sqm}$

IV.Second Floor: Total Built Up Area 21580sqft or 2005.57sqm

Seminar Hall / Auditorium measuring 12.19x38.56sqm,

Class room 1, 2\&3\&4AREA $=12.19 \times 9.14$ each,

Electronics Lab $-1 \& 2 \quad=12.19 X 16.38$,

\section{B. Description of Proposed System and its Operation}

As per the Energy audit report and recommendations .class rooms of first floor are proposed to shift to second floor so as to increase the air and light ventilation for the class rooms .no further major investment has been made.

All computer labs are proposed for multipurpose utilization example for placement training and language labs.

\section{Energy Saving Calculations}

\section{A. Energy Saving By Changing the Location of Class Rooms:}

$2^{\text {nd }}$ floor and $3^{\text {rd }}$ floor class room are better balance of more light $\&$ air.

GF labs are operated for $3 \mathrm{hr} /$ day or $5 \mathrm{hr} /$ day.

During 10AM-12.30PM\&12.10-4.30 PM

Where class rooms at the GF shall operate between 9PM-4PM

Number of classes to be relocated $=8$

Total number of operating hours per week= 6hrsx6days $\quad$ (excluding labs 6hrs/week) $\quad=36 \mathrm{hrs}$

Energy consumption/week/classroom

$$
\text { HoursxLightsxWatts }=36 \times 10 \times 50
$$

$=18000 \mathrm{Wh}$

Energy consumption per week for 8 classrooms

$=8 \times 18000 \mathrm{Wh}$

$=144000 \mathrm{Wh}$

Total Annual Energy consumption from lighting for 8 classrooms=weekly consumptionxNo of weeks

$=144000 \times 42$ weeks

$=6048000 \mathrm{Wh}$

Total Annual Energy consumption from lighting for 8 classrooms in Kwh

$=6048000 / 1000$

$=6048 \mathrm{kWh}$

Saving cost from lighting $\quad=6048 \times 3$

(Assume Tariff-1unit=Rs3/-) =Rs18144/--(1)

Energy consumption by fans load per week per classroom

hours $\mathrm{x}$ Lights $\mathrm{x}$ watts $\quad=36 \times 10 \times 80$

(Assume 1 fan $=80$ wattage) $\quad=28800 \mathrm{Wh}$

Energy consumption by fans per week for 8 classrooms

$$
\begin{aligned}
& =8 \times 28800 \mathrm{Wh} \\
& =230400 \mathrm{Wh}
\end{aligned}
$$

Total Annual Energy consumption from fan load for 8 classroom=Energy consumption/weekxno of weeks $=230400 \times 42$

$=9676800 \mathrm{Wh}$

Total Annual Energy consumption from lighting for 8 classrooms in Kwh

$=9677 \mathrm{kWh}$

Saving cost from fan load

$=9677 \times 3$

$$
=\text { Rs } 29031 /- \text {-(2) }
$$

In practice 50\% total working hours has been allowed to use hence the cost of saving $=50 \%$ of the total cost $=$ Rs14516/- 
Total Annual Energy cost saving from both lighting and fan load

$$
=\text { Rs47175/-----(3) }
$$

If elevator of $900 \mathrm{Kg}$ operates for consumes power of average value (Up-and-down) $6 \mathrm{Kw}$

It may operate for Extra load and time of students carrying to the second and third floor

Energy consumed by lifts operating for 3 hours per day

$=$ Elevator Power rating $\mathrm{x}$ operating hours $=6000 \times 3$

$=18000 \mathrm{Wh}$

$$
=18 \mathrm{kWh}
$$

Energy cost/day $(1 \mathrm{kWh}=\mathrm{Rs} 3 /-) \quad=18 \mathrm{x} 3$

$$
=\mathrm{Rs} 54 /-
$$

Annual energy consumption

$$
=54 \times 288
$$$$
=\text { Rs } 15552 /
$$

Net energy saving by changing the class room locations with additional facility of lift operating for limited hours

$$
\begin{array}{r}
(3)-(4)=\text { Rs }(47175-15552) \\
=\text { Rs31623/- }
\end{array}
$$

Note: Investment for elevator is optional therefore the payback period is not estimated

\section{B. Energy Saving By Replacing Water Cooler Operating Switch with Solar Operating Switch}

I. Water Cooler: It uses temperature switch work on heater Uses the switch working on temperature

\section{Calculation:}

If $1000 \mathrm{~W}$ Cooker consumes Electrical Power as long as the power is on then Energy consumed for full day in the conventional type water cooler:

Energy consumption $=$ Power rating of water cooler $\mathrm{x}$ operating hours $\quad=1000 \mathrm{x}$ 24

$$
\begin{aligned}
& =24000 \mathrm{Wh} \\
& =24 \mathrm{kWh} \\
& =24 \times 3 \\
& =\text { Rs } 72 /- \\
& =72 \times 365 \text { days } \\
& =\text { Rs } 26280 /----------- \text { (5) }
\end{aligned}
$$$$
\text { Energy cost per day } \quad=24 \times 3
$$

\section{Switch Solar Water Cooler:}

It uses a automated operating on solar radiations based on day hot condition

\section{II.Replaced by Solar Switch Operating Cooler.}

If operating up to the sun hot with charging facility for 4 more hours during night between 8 A.M to 8 P.M $=12$ hours.

If1000 W Cooler consumes electrical power by solar operating automated switch then Energy consumed for only day in the solar operating automated switch:

Annual Energy cost $=36 \times 365$ days

$$
=1000 \mathrm{~W} \times 12 \mathrm{hrs}
$$$$
=12000 \mathrm{Wh}
$$$$
=12 \mathrm{kWh}
$$$$
=12 \times 3
$$

Cost saving due to energy saving

$$
\begin{aligned}
& =\text { Rs36/- } \\
& =\text { Rs } 13140 /
\end{aligned}
$$

Additional cost for providing solar switch $=\mathrm{Rs} 3000 /$

Payback period for providing solar switch $=3000 / 36$

$$
=83 \text { days }
$$

\section{Energy Saving By Remote Controlled Fans}

I. Remote controlled fans versus conventionally controlled fans

Energy savings by controlled fans and conventionally controlled fans $=80 \mathrm{w} x$ operating hours (perdayperfan) $=80 \mathrm{~W} \times 10$ hours $/$ day $=800 \mathrm{Wh} /$ day $/$ fan

Energy cost per day per fan

$$
=0.8 \times 3=2.4 /-
$$


Cost of Energy consumption for 290 fans per day $\quad=$ Rs $2.4 \times 290$

= Rs696/-

Annual Cost of Energy consumption by regulator controlled fans

$$
=\text { Rs696x288days }
$$

$=$ Rs $200448 /--(7)$

II. Remote Controlled Fans Can Be Operating Based On User Requirement May Reduce The Operating Time.

Let us operate the fans on need basis as remote control is available, it will reduce the operating hours (Assume that the wattage is same)

$$
\begin{aligned}
& =560 \mathrm{Wh} / \text { day } \\
& =0.56 \mathrm{kWh} / \text { day } \\
& =0.56 \times 3 \\
& =\mathrm{RS} 1.68 / \text { day }
\end{aligned}
$$

Annual Energy consumption by remote controlled fan $=80 \mathrm{~W} \times 7 \mathrm{hr}$

$$
\begin{aligned}
& \quad=1.68 \times 290 \times 288 \\
& =\text { Rs. } 140314 /--8 \\
& =\text { Rs } 60134 /- \\
& \text { rating switch } \\
& =\text { Rs. } 400 \times 290 \\
& =\text { Rs } 174000 \\
& =174000 / 60134=2 \text { years }
\end{aligned}
$$

Cost saving (7)-(8)

Total cost of additional unit remote operating switch

Payback period

\section{Energy Saving By Replacing Desktopcomputter By Crt Monitor With Led Monitor} Computer with CRT monitor of 400w

Total Number of Systems

$$
\begin{aligned}
& =190 \\
& =190 \times 400 \\
& =76000 \mathrm{~W} \\
& =76 \mathrm{~kW}
\end{aligned}
$$

Total Energy consumption =Power Consumption $\mathrm{x}$ operating hours/day $=76 \times 8 \mathrm{kWh}$

Energy cost/ day

$$
\begin{aligned}
& =608 \mathrm{kWh} \\
& =608 \times 3 \\
& =\mathrm{Rs} 1824 /-
\end{aligned}
$$

Total Annual energy cost = Energy cost $/$ day $\mathrm{x}$ no of days

$$
=\operatorname{Rs} 1824 \times 288
$$

$$
\text { =Rs525312-----(9) }
$$

Computer with desktop LCD monitor of 250w

$$
\begin{aligned}
& \text { Total Power consumption } \\
& =190 \times 250 \\
& =475000 \mathrm{watts} \\
& =47.5 \mathrm{~kW} \\
& \text { Total Energy consumption per day } \\
& =47.5 \times \text { 8hours } \\
& =380 \mathrm{kWh} \\
& =380 \times 3 \\
& =\mathrm{Rs} 1140 /- \\
& =\text { Rs1140x288days }
\end{aligned}
$$

\section{E. Energy Saving By Replacing Desktop Led Monitor With Laptop}

I. LAPTOP power consumption $=40 \mathrm{~W}$

Power consumption by replacing all desktop LCD monitor with laptop=190computers $\mathrm{x} 40$ watts each $=7600 \mathrm{w}$

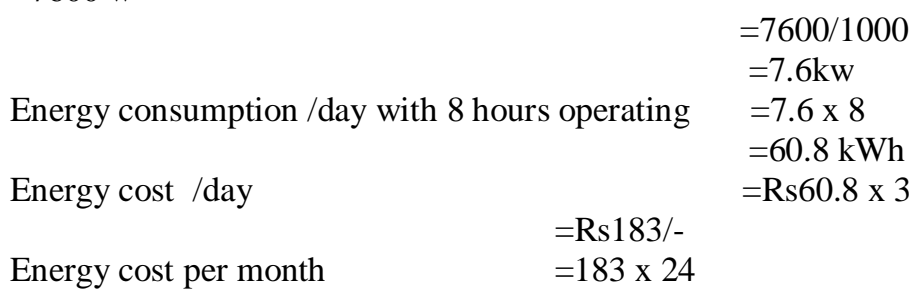




$\begin{array}{ll} & =\text { Rs4392/- } \\ & =4392 \times 12 \\ & =\text { Rs52704/-11 } \\ \text { Cost Saving (10-11) } & =\text { Rs328320-52704 } \\ \text { 275616/------12 } & \\ \text { Cost Of Computer } & =\text { Rs 20000/-to 23000/- } \\ \text { Cost Of Laptop } & =\text { Rs 30000/-to 40000/- } \\ \text { Extra Cost Of Replacement } & =\text { Rs 7000/ System } \\ \text { Replacing All } & =\text { Rs 7000 X 190 } \\ \text { Payback period (13/12) } & =\text { Rs } 1330000 /-----13 \\ & =4.8 \text { year } \\ & 58 \text { months }\end{array}$

III. Additional Energy Save By Keep On All Systems Only When It Is Used Or Avoid Using The System In Sleepy Mode

Keep all the system in sleep mode during non operationg hours. Let systems are used effectively for 6 hours a day.

The duration of average sleeping mode $=2$ hours/system

Thus the power consumed by systems during sleeping mode

(LCD monitor desktop)

$$
\begin{aligned}
& =190 \times 2 \mathrm{hrs} \\
& =380 \mathrm{hrs}
\end{aligned}
$$

Energy consumed by sleeping mode computer/day $=11400 \mathrm{Wh}$

Energy in $\mathrm{kWh} /$ day $\quad=11400 / 1000$

$=11.4 \mathrm{kWh}$

Cost /day

$=11.4 \mathrm{X} 3$

$=\mathrm{Rs} 34 /-$

Cost of Energy consumption/month

$=\mathrm{Rs} 34$ x 24 day

$=\mathrm{Rs} 816 /-$

Annual cost of energy

$=$ Rs $816 /-\mathrm{x} 12 \mathrm{months}$

$=$ Rs9792

As we use the laptop based on the charged facility as well as practice to use only when required by default the energy cost same will be added to the laptop facility

Net cost of saving by replacing all desktop LCD computers with LAPTOP

$$
\begin{aligned}
& =\text { Rs }(275616+9792) \\
& =\text { Rs 285408/- }
\end{aligned}
$$

Net payable period for replacing all desktop systeswithlaptop $=$ Rs $1330000 / 285408$

$$
\begin{aligned}
& =4.6 \text { years } \\
& =56 \text { months }
\end{aligned}
$$

\section{F. Energy Saving By Operating The Photocopier Machine Only When Required Or Avoiding Using Machine In The Sleepy Mode Which Consume The Energy As Follows \\ Power Consumption of Xerox M/C in Non Operating Mode

$$
=1 \times 100 \mathrm{~W}
$$

Energy Saving for Approximate Sleepy Mode Hours For 2hours In A Day

$=100 \mathrm{~W} \times 2 \mathrm{hr} /$ day

Energy in kWh

$$
\begin{aligned}
& =200 \mathrm{Wh} / \text { Day } \\
& =200 / 1000 \\
& =0.2 \mathrm{kWh} / \text { day } \\
& =0.2 \mathrm{kWh} \times 24 \text { days } \\
& =4.8 \mathrm{kWh} \\
& =4.8 \text { Units } \\
& =4.8 \times 3 \\
& =\text { Rs } 14.4 /- \\
& =\text { Rs } 14.4 \times 12 \\
& =\text { Rs } 173 /--14
\end{aligned}
$$

Energy for a Month 


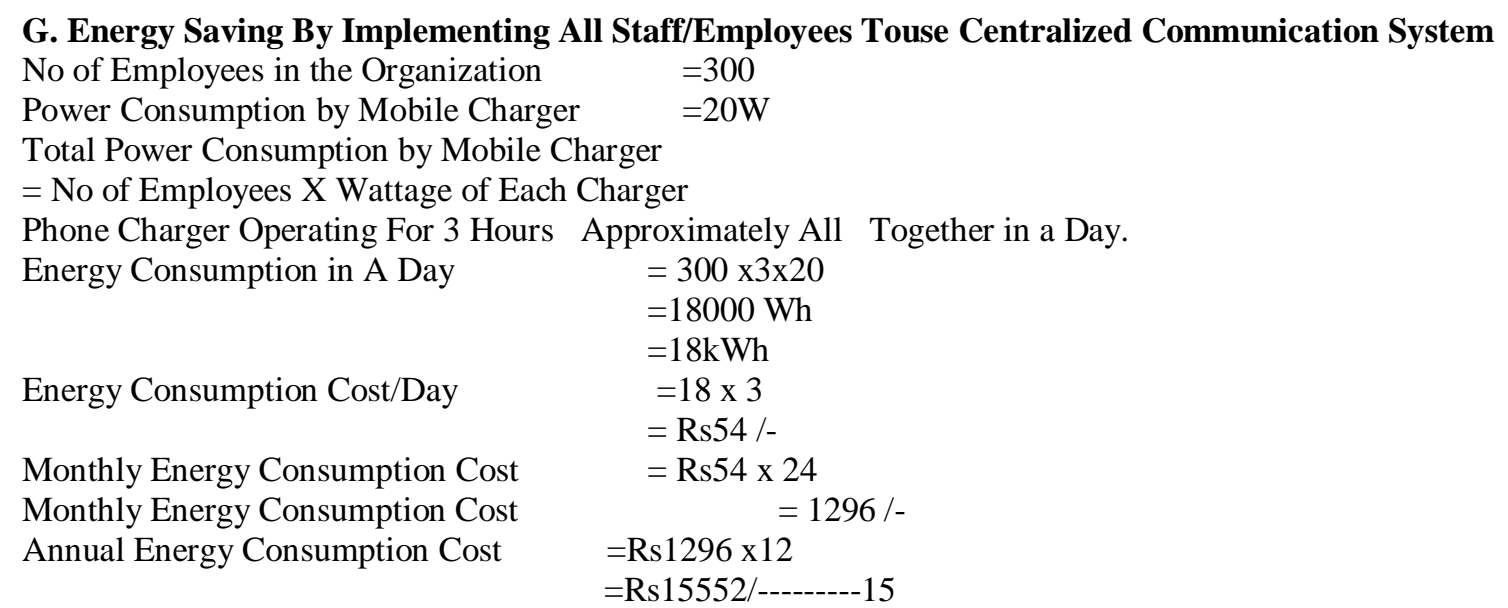

If Mobiles Are Banned To Use by Providing Common Facility, Then Power Pack Along With Cordless Telephone Set Has To Used

Tele Phone Power Pack Power Consumption $\quad=10 \mathrm{~W}$

No of Tele Phone Power Packs Required Will Be Based On the Number of Cordless Telephone We Use

Total Power Consumption $=6(2$ Set To Each Floor $)$

Operating Time 6 $=600 \mathrm{~W}$

Energy Consumed /Day

$=10$ Hours

$=600 \times 10$

$=6000 \mathrm{Wh}$

Energy Consumed /Day in Kwh

$=6 \mathrm{Kwh}$

Annual Energy Cost

$=6 \times 3 \times 288$

$=$ Rs $5184 /--16$

Cost saving (15-16) - Rs (15552-5184)=Rs10368/-

Payback period calculation:-

Cost Of Power Pack =Rs500 × 6

$=3000 /-$

Payback period $=3000 / 10368=3$ months

\section{H. Energy Saving By Replacing All Fluorescent Lamps by Cfl}

I. Energy Saving Cost Estimation of FL

Total no. of $\mathrm{F}$ lamps $\quad=266$

Actual wattage of FL inclusive of choke $\quad=50 \mathrm{~W}$

Energy consumed by FL for an operating of 12 hour per day $=266 \times 50 \times 12$

$$
=159600 \text { watt-hours }
$$

Energy consumed by FL for an operating of 12 hour per month

$$
\begin{aligned}
& =159600 \times 24 \text { working days } \\
& =3830400 \mathrm{Wh} \\
& =3830.4 \mathrm{kWh}
\end{aligned}
$$

Monthly Energy consumed cost by FL=Rs $3830.4 x 3$

$$
=\text { Rs11491/- }
$$

Annual Energy Consumed cost by FL=Rs11491x12

$$
=\text { Rs137894/--17 }
$$

II.ENERGY SAVING BY REPLACING THE CFL OF EQUAL SIMILARITIES OF FLUROSCENT LAMP 13 watt $\mathrm{CFL}$ can give an illumination $\mathrm{o} / \mathrm{p}=800$ lumens

40 watt FL can give an illumination $\mathrm{o} / \mathrm{p}=2400$ lumens

Therefore Number of 13 watts of C FL required to get the illumination level of 2400 lumens $=3$

45 watts of $\mathrm{CFL}=50$ watts of $\mathrm{FL}$ in terms of illumination output (The actual wattage of 13 watt $\mathrm{CFL}=15$ watt inclusive of choke)

Total power consumption by CFL $\quad=15 \mathrm{X} 3$

$$
=45 \text { watts }
$$


Hence the total wattage of FL

$$
\begin{aligned}
& =266 \times 50 \text { watts } \\
& =13300 \text { watts }
\end{aligned}
$$

Number of CFL required to replace all FL @ the rate of

13 watts $\mathrm{x} 3,39$ wattsCFL=50watts FL. $=13300 / 39$ watts $=295$

Power saving by CFL replacement $\quad=295 \times 11$ watts

$$
=3245 \text { watts }
$$

Energy consumption from CFL for an operated average hour/day for 12 hours

$$
=38940 \mathrm{Wh}
$$

Daily cost of energy consumption by CFL $=39 \times 3 \mathrm{kWh}$

Saving Cost of energy /day = Rs.117/-

Monthly Energy cost saving due to CFL = Rs. 117x 24 days

$=$ Rs $2808 /-$

Annual Energy cost saving 2808x12=Rs33696/-

Payback Period Calculation:-

Investment on 1 CFL of 13 watts = Rs90/-

Total cost of replacement $\quad=$ Rs $295 \times 90$

$=\mathrm{Rs} 26550 /-$

Payback Period

$=26550 / 33696$

Formula used:

$=9$ months 11 days

\author{
Number of fittings required $=\frac{\mathrm{E} \times \mathrm{A}}{\mathrm{O} \times \mathrm{UF} \times \mathrm{MF}}$ \\ Where $\mathrm{N}=$ Number of fittings required \\ $\mathrm{E}=$ Required illumination (lux) \\ $\mathrm{A}=$ working area (sqmtr) \\ $\mathrm{O}=$ Luminous flux produced per lamp (lumens), \\ $\mathrm{UF}=$ Utilization factor \\ $\mathrm{MF}=$ Maintenance factor
}

I. REPLACING LASER PRINTER BY INKJET PRINTER

Number of printers to be replaced $\quad=12$

I. Energy and Cost Saving Calculation for Laser Printers

Power consumption by Laser printer $\quad=12 \times 150$ watts

Power Consumption by Laser printers $\quad=1800 \mathrm{~W}$

Normalized operating hour $-8 \mathrm{hr}$ in a day

Energy consumed /day

$=1800$ watts $\mathrm{x} 8 \mathrm{hours}$

$=14400 \mathrm{Wh}$

Energy cost /day

(1 kWh=1unit)

$=14.4$ units

$=14.4 \mathrm{X} 3$

$=\mathrm{Rs} 43.2 /$

Energy cost per month for 24 working day $=43.2 \times 2$

$=$ Rs1036.8/-

Annual Energy cost

$=\mathrm{Rs} 1036.8 \times 12$

$=$ Rs12442/-------18

II.Energy and cost saving calculation for inkjet printers

Power consumption by inkjet printers $\quad=12 \times 80$

$=960 \mathrm{watts}$

Normalized operating hour $-8 \mathrm{hr}$

Energy consumption /day

$=960 \times 8$

$=7680 \mathrm{Wh}$

Energy consumption in $\mathrm{kWh} /$ day

$=7680 / 1000$

$=7.6 \mathrm{kWh}$

$=7.68 \times 3$

Daily Cost of energy consumption

$=$ Rs $23.04 /-$

Monthly cost of Energy consumption for 24 working days in a month

$=23.04 \times 24$

$=\mathrm{Rs} 552 / \mathrm{-}$ 
Annual cost of Energy consumption $\quad=$ Rs $552 \times 12$

$=$ Rs 6624/---------19

Annual energy cost saving $(18-19)=$ Rs $12442-6624$

$$
=\text { Rs5818/- }
$$

\section{A Typical Summary Of Energy Expenses Based On Monthly and Annual Utility Bills}

Kerala, India

Energy Auditing Of Jawaharlal College Of Engineering And Technology, Lakkidi, Palakkad District,

\begin{tabular}{|c|c|c|c|c|}
\hline $\begin{array}{l}\text { Mode of energy } \\
\text { saving }\end{array}$ & $\begin{array}{l}\text { Cost to be saved in } \\
\text { Rupees }\end{array}$ & $\begin{array}{l}\text { Investment in } \\
\text { Rupees }\end{array}$ & $\begin{array}{l}\text { Payback } \\
\text { period }\end{array}$ & feasibility \\
\hline $\begin{array}{l}\text { Replacing } \\
\text { Fluorescent Lamps } \\
\text { By CFL }\end{array}$ & 33696 & 26550 & 9 months & $\begin{array}{l}\text { Technically } \\
\& \\
\text { Economicall } \\
\text { y feasible }\end{array}$ \\
\hline $\begin{array}{l}\text { Replacement Of } \\
\text { Laser Printer By } \\
\text { Inkjet Printer }\end{array}$ & 5818 & Nil & Nil & $\begin{array}{l}\text { Technically } \\
\text { feasible }\end{array}$ \\
\hline $\begin{array}{l}\text { changing the } \\
\text { location of class } \\
\text { rooms }\end{array}$ & 31625 & Nil & Nil & $\begin{array}{l}\text { Technically } \\
\text { feasible }\end{array}$ \\
\hline $\begin{array}{l}\text { Using solar } \\
\text { operating water } \\
\text { cooler }\end{array}$ & 13140 & 3000 & 83days & $\begin{array}{l}\text { Technically } \\
\text { feasible }\end{array}$ \\
\hline $\begin{array}{l}\text { Using remote } \\
\text { controlled fans }\end{array}$ & 60134 & 174000 & 2years & $\begin{array}{l}\text { Technically } \\
\& \\
\text { economicall } \\
\text { y feasible }\end{array}$ \\
\hline $\begin{array}{l}\text { Replacing desktop } \\
\text { crtcomputer with } \\
\text { lcd monitor }\end{array}$ & 196992 & 133000 & 58months & $\begin{array}{l}\text { Technically } \\
\& \\
\text { economicall } \\
\text { y feasible }\end{array}$ \\
\hline $\begin{array}{l}\text { Replacing LCD } \\
\text { Desktop with LA } \\
\text { PTOP }\end{array}$ & 285408 & 133000 & 56months & $\begin{array}{l}\text { Technically } \\
\text { feasible }\end{array}$ \\
\hline $\begin{array}{l}\text { Replacing CRT } \\
\text { monitor with LCD } \\
\text { monitor }\end{array}$ & 196992 & $5700000 /-$ & 5 years & $\begin{array}{l}\text { Technically } \\
\text { feasible }\end{array}$ \\
\hline $\begin{array}{l}\text { Operating the } \\
\text { photocopier } \\
\text { machine in active } \\
\text { mode }\end{array}$ & 180/- & Nil & Nil & $\begin{array}{l}\text { Technically } \\
\text { feasible }\end{array}$ \\
\hline $\begin{array}{l}\text { Centralized } \\
\text { Communication } \\
\text { System }\end{array}$ & 5184/- & 9000/- & 3months & $\begin{array}{l}\text { Technically } \\
\text { feasible }\end{array}$ \\
\hline
\end{tabular}

ANNEXURE-1

Energy Auditing: Office Equipment

Note: $\mathrm{SL}=$ Sleep Mode, $\mathrm{ST}=\mathrm{Standby}, \mathrm{OP}=\mathrm{In}$ Operation, $\mathrm{SR}=$ Surge

\begin{tabular}{|c|c|c|}
\hline Equipment & Wattage & Comments \\
\hline $\begin{array}{l}\text { ADSL Modem } \\
\text { Power } \\
\text { pack }\end{array}$ & $\begin{array}{l}\text { OP } \\
10- \\
20 W\end{array}$ & $\begin{array}{l}\text { In most offices and many households, this represents a } \\
\text { relatively small but continuous load as the modem operates } 24 \\
\text { hours a day. }\end{array}$ \\
\hline CRT Monitor & $\begin{array}{l}\text { OP } \\
100- \\
120 W\end{array}$ & $\begin{array}{l}\text { CRT monitors consume a lot of power, much of which is } \\
\text { wasted as heat, and represent the largest power consumption } \\
\text { component in a typical desktop computer. Emit potentially } \\
\text { harmful radiation. Fortunately, most CRT monitors these days }\end{array}$ \\
\hline
\end{tabular}




\begin{tabular}{|c|c|c|}
\hline & & $\begin{array}{l}\text { are legacy equipment as new computers are generally supplied } \\
\text { with LCD monitors. Unfortunately, most CRT monitors end up } \\
\text { in landfill. }\end{array}$ \\
\hline Desktop Computer & $\begin{array}{l}\text { OP } \\
150 \mathrm{~W}\end{array}$ & $\begin{array}{l}\text { Power consumption will differ significantly depending on } \\
\text { whether a CRT or LCD monitor is used. In home and office } \\
\text { situations where it is necessary to run multiple desktop } \\
\text { computers, it may be possible to make significant power } \\
\text { savings by running a single terminal server computer with } \\
\text { several LCD monitors and keyboards attached. Terminal server } \\
\text { computers can also greatly simplify network management, } \\
\text { software upgrades, etc. }\end{array}$ \\
\hline Fax Machine & $\begin{array}{l}\text { ST } \\
10-30 \mathrm{~W} \\
\text { OP } \\
100 \mathrm{~W}\end{array}$ & $\begin{array}{l}\text { Fax machines generally sit idle most of the time, so stand-by } \\
\text { power consumption is the biggest factor in their overall energy } \\
\text { consumption. Thermal fax machines and inkjet fax machines } \\
\text { have a stand-by power consumption of around } 10 \mathrm{~W} \text { to } 20 \mathrm{~W} \text {, } \\
\text { while laser faxes have a stand-by power consumption of around } \\
30 \mathrm{~W} \text {. Thermal fax machines are generally cheaper to purchase, } \\
\text { but thermal paper costs a significantly more than plain paper, is } \\
\text { not recyclable, and must be photocopied for long term storage. }\end{array}$ \\
\hline Inkjet Printer & $\begin{array}{l}\text { OP } \\
120 W\end{array}$ & $\begin{array}{l}\text { Inkjet printers use relatively little power in comparison to laser } \\
\text { printers. From an energy consumption point of view, inkjets are } \\
\text { preferable to lasers. Unfortunately, they typically cost more to } \\
\text { run on a cost-per-print basis and sometimes produce less than } \\
\text { optimum results. }\end{array}$ \\
\hline Laptop Computer & $\begin{array}{l}\text { OP } \\
15-40 \mathrm{~W}\end{array}$ & $\begin{array}{l}\text { Laptop computer power consumption is typically } 10 \% \text { to } 25 \% \\
\text { of that of a desktop computer. In situations such as an office or } \\
\text { home office, where computers may operate for } 8 \text { to } 10 \text { hours a } \\
\text { day, this difference is significant and could represent an energy } \\
\text { saving of up to } 1 \mathrm{kWh} \text { per day. }\end{array}$ \\
\hline Laser Printer & $\begin{array}{l}\text { ST } \\
25-80 \mathrm{~W} \\
\text { OP } 150- \\
1100 \mathrm{~W}\end{array}$ & $\begin{array}{l}\text { Laser printers consume significant amounts of power even } \\
\text { when in standby mode. Over the course of an } 8-10 \mathrm{hr} \text { working } \\
\text { day, a laser printer could consume around } 1 \mathrm{kWh} \text { of energy. On } \\
\text { the other hand, laser printers are cheaper to run on a cost-per- } \\
\text { page basis and generally produce better results. Both the } \\
\text { number of laser printers used, and the number of hours the are } \\
\text { operated for, should be minimized. As with printing of any } \\
\text { kind, office procedures should be developed which minimize } \\
\text { the need for printing to paper. }\end{array}$ \\
\hline LCD Monitor & $\begin{array}{l}\text { OP } \\
30-50 \mathrm{~W}\end{array}$ & $\begin{array}{l}\text { LCD monitors typically require about } 30 \% \text { of the power } \\
\text { required for a CRT monitor with the same screen area. In } \\
\text { addition, the amount of heat generated by an LCD monitor is } \\
\text { considerably less than a CRT monitor, resulting in a lower load } \\
\text { on air conditioning. Building cooling needs may be decreased } \\
\text { by up to } 20 \% \text {. }\end{array}$ \\
\hline $\begin{array}{l}\text { Mobile Phone } \\
\text { Charger }\end{array}$ & $\begin{array}{l}\text { OP } \\
10-20 \mathrm{~W}\end{array}$ & Most of the mobile charger consumes power during charging. \\
\hline $\begin{array}{l}\text { Photo } \\
\text { copier }\end{array}$ & $\begin{array}{l}\text { SM } \\
7-30 \mathrm{~W} \\
\text { ST } \\
40- \\
300 \mathrm{~W} \\
\text { OP 200- } \\
1300 \mathrm{~W}\end{array}$ & $\begin{array}{l}\text { Most of the energy used in a photocopier is consumed by the } \\
\text { hot rollers, which are usually kept hot on stand-bay, consuming } \\
\text { from } 40 \text { to } 300 \mathrm{~W} \text {. Significant energy savings ( } 40 \% \text { to } 60 \% \text { ) can } \\
\text { be made by ensuring that photocopiers are switched off at night } \\
\text { and on weekends. Some photocopiers consume up to } 30 \text { watts } \\
\text { even when switched off, so photocopiers should be switched off } \\
\text { at the power outlet to ensure they are really "off". }\end{array}$ \\
\hline $\begin{array}{l}\text { Tele } \\
\text { phone Power } \\
\text { pack }\end{array}$ & $\begin{array}{l}\text { OP } \\
10 \mathrm{~W}\end{array}$ & $\begin{array}{l}\text { Many landline telephones today (eg. portable/wireless phones) } \\
\text { use power packs, which represent a relatively small but } \\
\text { continuous load as the telephone operates } 24 \text { hours a day. If } \\
\text { possible, this type of telephone should be avoided. }\end{array}$ \\
\hline
\end{tabular}

ANNEXURE-2 


\section{Light Level Recommendations in LUX}

Stairways and corridors

$150-300$

Storage rooms

$100-500$

General Classrooms

$250-550$

General Offices

$300-750$

Restrooms/toilet rooms

$150-300$

Gymnasiums

general exercise $\quad 300-400$

basketball

$750-1000$

Auditoriums and assembly rooms

$100-200$

Library

$300-500$

Maintenance room

300

Science laboratory

$300-500$

Woodworking shop

$300-750$

Office Landscapes

$500-750$

Public areas with dark surroundings

$20-50$

Simple orientation for short visits

$50-100$

Warehouses, Theaters, Archives

roceries, Show Rooms,

Laboratories

$300-500$

Supermarkets, Mechanical

Workshops

$500-750$

Normal Drawing Work, Detailed

Mechanical Workshops,

Operation Theatres

letailed Drawing Work, Highly

retailed Mechanical Works

$1500-2000$

Performance of visual tasks of low contrast and very small size for prolonged periods of time

Performance of very prolonged and exacting visual tasks

Performance of very special visual tasks of extremely low contrast and small size

$10000-20000$

\section{Conclusion}

The Proposed project gives strong warning to the consumer not only interms of the energy bills also the energy crisis in the near future to all sectors of people and in this project the recommendations reduces the around $15-20 \%$ of the energy and $25-30 \%$ of cost reduction excluding some issues takes more payback period and some are economically not fit will also be taken in to account in a long run. There is a scope of improvement to include the advanced lighting scheme to reduce further $10 \%$ of the cost.

\section{Acknowledgements}

I am deeply indebted to our Management for supporting and facilities to generate the Energy Audit Report. 
I thank PRO, JCET for having given information and suggestions and civil and interior drawings to carry out this project. We thank Dr.U.LazerJohn, Director-Academics, JCET, for having given us extreme moral support and permissions to use the literature and data collection during working hours.

I thank Dr.A.S.Devaraja, principal, JCET for his consistent encouragement to complete the report and authorizing us as bonafide students of this College to be eligible for participation.

I thank Sri.Sugumaran, Administrative Manager JCET for valuable guidance and permissions to use the college layout to propose the changes in the existing system

I thank all our Department faculty members of Electronics and Communication Engineering and Faculty members of Electrical and Electronics Engineering for their suggestions to carry out this project.

I thank General Secretary, Energy conservation society, Kerala for having given us an opportunity to participate in $2^{\text {nd }}$ National Energy auditing Competition (NEAC-2012).

I also thank my wife and daughter for their encouragement to complete this assignment.

\section{References}

[1] Utilization of Electric power by N.V.Surya Narayana.New age international publishers.

[2] Utilization of Electrical power byR.K.Rajput.New age international publishers

[3] Designing with Light- A lighting Handbook - Anil Walia-International Lighting Academy

[4] Handbook of Functional requirements on Industrial Buildings-SP-32- Bureau of Indian Standards

[5] Efficient Use of Electricity In Industries- Devki Energy Consultancies Pvt. Ltd., Vadodara

[6] Websites/Product Information CDs of the following manufacturers:

I. Crompton Greaves Lighting Division

II. Bajaj Electricals

III. GE lighting, USA

IV. Watt Stopper Inc, USA

V. Vergola India Ltd

VI. Lighting research centre, USA

VII. LBNL, USA

[7] Free guide to achieving financial success as an energy auditor by Energy audit Institute-USA.

[8] working manual on energy auditing by the asian productivity organization(apo) and national productivity council (npc) in new delhi, india, conducted in 2007 , 